\title{
The Rietveld Refinement of Beryls from Pegmatitic System at Piława Górna, Góry Sowie Block, SW Poland
}

\author{
S. ZeleK-Pogudz ${ }^{a *}$, M. ZuBKo ${ }^{b}$ AND A. PIECZKA ${ }^{a}$ \\ ${ }^{a}$ Faculty of Geology, Geophysics and Environmental Protection, AGH University of Science and Technology, \\ Kraków, Poland \\ ${ }^{b}$ Institute of Materials Science, University of Silesia, Chorzów, Poland
}

\begin{abstract}
The studied beryl crystals came from the Julianna pegmatitic system exposed in the Dolnośląskie Surowce Skalne S.A. quarry at Piława Górna. This mineral occurs here in various forms and colours (green, yellow, white, pinkish and blue) in almost all pegmatite bodies. The paper describes the relationship between the structure and chemical composition of different coloured beryl crystals.
\end{abstract}

DOI: 10.12693/APhysPolA.130.898

PACS/topics: 91.65.An

\section{Introduction}

The beryl group consists of five mineral species: beryl, ${ }^{2 \mathrm{a}, 2 \mathrm{~b}} \square^{\mathrm{T} 2} \mathrm{Be}_{3}^{\mathrm{O}} \mathrm{Al}_{2}\left({ }^{\mathrm{T} 1} \mathrm{Si}_{6} \mathrm{O}_{18}\right)$; bazzite, ${ }^{2 \mathrm{a}, 2 \mathrm{~b}} \square^{\mathrm{T} 2} \mathrm{Be}_{3}^{\mathrm{O}} \mathrm{Sc}_{2}\left({ }^{\mathrm{T} 1} \mathrm{Si}_{6} \mathrm{O}_{18}\right)$; stoppaniite, ${ }^{2 \mathrm{a}, 2 \mathrm{~b}} \square^{\mathrm{T} 2} \mathrm{Be}_{3}^{\mathrm{O}} \mathrm{Fe}_{2}^{3+}\left({ }^{\mathrm{T} 1} \mathrm{Si}_{6} \mathrm{O}_{18}\right)$; pezzottaite, ${ }^{2 \mathrm{a}} \mathrm{Cs}^{2 \mathrm{~b}} \square^{\mathrm{T} 2}\left(\mathrm{LiBe}_{2}\right)^{\mathrm{O}} \mathrm{Al}_{2}\left({ }^{\mathrm{T} 1} \mathrm{Si}_{6} \mathrm{O}_{18}\right)$; andindialite, ${ }^{2 \mathrm{a}, 2 \mathrm{~b}} \square^{\mathrm{T} 2}\left(\mathrm{Al}_{2} \mathrm{Si}\right){ }^{\mathrm{O}} \mathrm{Mg}_{2}\left[{ }^{\mathrm{T} 1}\left(\mathrm{Al}_{2} \mathrm{Si}_{4}\right) \mathrm{O}_{18}\right]$, where superscripts give occupied site symbols and $\square$ is a symbol of vacancy. Only beryl is widespread as a common accessory component of many rare-element pegmatites, sometimes found in the form of perfectly transparent and variously coloured crystals of gemstone quality.

Beryl, bazzite, stoppaniite, and indialite have hexagonal symmetry (space group $P 6 / m c c$ ), whereas pezzottaite is rhombohedral with space group $R 3 c[1,2]$. In the structure of all these minerals, flat $\mathrm{Si}_{6} \mathrm{O}_{18}$ rings are spatially arranged one above another and linked by $\mathrm{Be}$ tetrahedra (T2) and $\mathrm{Al}$ octahedra $(\mathrm{O})$, forming a lattice with open channels oriented along the crystallographic $c$ axis. The channels include 5.1 Ålarge cavities separated by smaller constrictions of approximately 2.8 Åin diameter. Alkali cations $\left(\mathrm{Na}^{+}, \mathrm{K}^{+}, \mathrm{Rb}^{+}\right.$and $\left.\mathrm{Cs}^{+}\right)$, and also traces of $\mathrm{Ca}^{2+}$ and water molecules can be located within the channels in two different positions: $2 \mathrm{a}$ and $2 \mathrm{~b}$ with coordinates $(0,0,1 / 4)$ and $(0,0,0)$, respectively [3].

Recently, compositionally and colouristic differentiated beryl crystals have been found in a pegmatitic system at Piława Górna, the Góry Sowie Block, SW Poland [4]. Beryl is a common minor to accessory component of these pegmatites and occurs in the form of non-transparent, greenish to yellowish and bluish crystals, up to $\approx 30 \mathrm{~cm}$ in length, in NYF-affiliated (Nb-Y-F) bodies, and yellowish, white and pinkish crystals, up to $\approx 10-12 \mathrm{~cm}$ in length, in LCT-affiliated ( $\mathrm{Li}-\mathrm{Cs}-\mathrm{Ta}$ ) pockets.

*corresponding author; e-mail: zelek@geol.agh.edu.pl

\section{Experimental details}

Electron microprobe analyses of beryl were performed at the Inter-Institute Analytical Complex for Minerals and Synthetic Substances at the University of Warsaw, using a Cameca SX 100 electron microprobe operating in wavelength-dispersive mode under the following conditions: accelerating voltage of $15 \mathrm{kV}$, beam current of $20 \mathrm{nA}$, beam diameter of $3 \mu \mathrm{m}$, peak count-time of $20 \mathrm{~s}$, background time of $10 \mathrm{~s}$. Standards, analytical lines, diffracting crystals and mean detection limits (in wt\%) were as follows: albite $-\mathrm{Na}\left(K_{\alpha}, \mathrm{TAP}, 0.02\right)$, diopside $\mathrm{Si}\left(K_{\alpha}, \mathrm{TAP}, 0.02\right), \mathrm{Mg}\left(K_{\alpha}, \mathrm{TAP}, 0.01\right)$ and $\mathrm{Ca}\left(K_{\alpha}\right.$, PET, 0.02), orthoclase - $\mathrm{Al}\left(K_{\alpha}, \mathrm{TAP}, 0.01\right)$ and $\mathrm{K}\left(K_{\alpha}\right.$, PET, 0.02), rutile $-\mathrm{Ti}\left(K_{\alpha}\right.$, LPET, 0.02), rhodonite - Mn $\left(K_{\alpha}\right.$, LIF, 0.06), hematite - Fe $\left(K_{\alpha}\right.$, LIF, 0.06), $\mathrm{Cr}_{2} \mathrm{O}_{3}-\mathrm{Cr}\left(K_{\alpha}\right.$, LPET, 0.06), $\mathrm{V}_{2} \mathrm{O}_{5}-\left(K_{\alpha}\right.$, LIF, 0.06), pure Sc - Sc $\left(K_{\alpha}\right.$, LPET, 0.02), Rb-glass - Rb $\left(L_{\alpha}\right.$, TAP, 0.04) and Cs-glass - Cs ( $L_{\alpha}$, LPET, 0.07). The raw data were reduced with the PAP routine [5]. Compositional formulae were normalized to $18 \mathrm{O}$ atoms per formula unit (apfu), with $\mathrm{Li}_{2} \mathrm{O}$ and $\mathrm{BeO}$ iterated on the basis of the total sum of the analyzed tetrahedral and octahedral cations and calculated Li and Be equal to 11 apfu. It was assumed that substitutions in the $\mathrm{T} 1, \mathrm{~T} 2$, and $\mathrm{O}$ sites are completely charge balanced by channel cations, i.e. ${ }^{\mathrm{T} 1} \mathrm{Al}+{ }^{\mathrm{O}} \mathrm{Mg}+{ }^{\mathrm{O}} \mathrm{Fe}+{ }^{\mathrm{O}} \mathrm{Mn}-{ }^{\mathrm{O}} \mathrm{Ti}-2^{\mathrm{T} 2} \mathrm{Si}-{ }^{\mathrm{T} 2} \mathrm{Al}+{ }^{\mathrm{T} 2} \mathrm{Li}=$ $\mathrm{Na}+\mathrm{K}+\mathrm{Rb}+\mathrm{Cs}+2 \mathrm{Ca}$, according to the procedure proposed by Aurisicchio et al. [6].

The X-ray diffraction experiments were carried out on powdered samples in the range of $10-140^{\circ}(2 \theta)$ using Empyrean PANalytical diffractometer (Co $K_{\alpha}$ radiation with $\lambda=1.78901 \AA$ ) equipped in PIX-cell ${ }^{3 \mathrm{D}}$ detector. The phase identification was carried out using the X'Rayan computer program and X-ray standard patterns in the form of ICDD files (card 09-0430). The unit-cell refinement (Table I) and Rietveld structure refinement were made using the FullProf Suite computer program package [7]. 


\section{Results and discussion}

The averaged chemical composition for green and light green beryl crystals, coming from the NYF-affiliated bodies, can be defined as $\left(\mathrm{Na}_{0.04-0.14} \mathrm{Rb}_{0.00-0.01} \mathrm{Cs}_{0.00-0.02}\right)\left(\mathrm{Be}_{2.18-3.00} \mathrm{Li}_{0.00-0.56}\right.$ $\left.\mathrm{Al}_{0.00-0.02} \mathrm{Si}_{0.00-0.25}\right)\left(\mathrm{Al}_{1.80-1.97} \mathrm{Mg}_{0.00-0.08} \mathrm{Fe}_{0.01-0.14}\right)$ $\left(\mathrm{Si}_{5.99-6.00} \mathrm{Al}_{0.00-0.01}\right) \mathrm{O}_{18}$ and $\left(\mathrm{Na}_{0.04-0.12} \mathrm{Rb}_{0.00-0.01}\right.$ $\left.\mathrm{Cs}_{0.00-0.02}\right)\left(\mathrm{Be}_{2.23-2.98} \mathrm{Li}_{0.02-0.54} \mathrm{Si}_{0.00-0.24}\right)\left(\mathrm{Al}_{1.90-1.98}\right.$ $\left.\mathrm{Mg}_{0.00-0.03} \mathrm{Fe}_{0.01-0.08}\right)\left(\mathrm{Si}_{5.98-6.00} \mathrm{Al}_{0.00-0.02}\right) \mathrm{O}_{18}$, respectively, while for a bluish crystal as

$\left(\mathrm{Na}_{0.08-0.26} \mathrm{~K}_{0.00-0.01} \mathrm{Rb}_{0.00-0.01} \mathrm{Cs}_{0.00-0.05} \mathrm{Ca}_{0.00-0.01}\right)$ $\left(\mathrm{Be}_{2.36-2.95} \mathrm{Li}_{0.05-0.49} \mathrm{Si}_{0.00-0.17}\right)\left(\mathrm{Al}_{1.95-1.98} \mathrm{Mg}_{0.00-0.01}\right.$ $\left.\mathrm{Fe}_{0.02-0.05} \mathrm{Mn}_{0.00-0.01}\right) \mathrm{Si}_{6.00} \mathrm{O}_{18}$. Pinkish and light pinkish crystals originated from a nest of (Cs,Li)bearing mineralization have the compositions $\left(\mathrm{Na}_{0.06-0.32} \mathrm{~K}_{0.00-0.05} \mathrm{Rb}_{0.00-0.02} \mathrm{Cs}_{0.01-0.74} \mathrm{Ca}_{0.00-0.03}\right)$ $\left(\mathrm{Be}_{1.61-2.79} \mathrm{Li}_{0.16-1.12} \mathrm{Si}_{0.00-0.28}\right)\left(\mathrm{Al}_{1.97-2.00} \mathrm{Mg}_{0.00-0.02}\right.$ $\left.\mathrm{Fe}_{0.00-0.02} \mathrm{Mn}_{0.01}\right)\left(\mathrm{Si}_{5.99-6.00} \mathrm{Al}_{0.00-0.01}\right) \mathrm{O}_{18}$, respectively, while a yellowish crystal

$\left(\mathrm{Na}_{0.02-0.34} \mathrm{~K}_{0.00-0.01} \mathrm{Rb}_{0.00-0.01} \mathrm{Cs}_{0.00-0.32} \mathrm{Ca}_{0.00-0.01}\right)$ $\left(\mathrm{Be}_{1.64-2.74} \mathrm{Li}_{0.20-1.09} \mathrm{Si}_{0.06-0.27}\right)\left(\mathrm{Al}_{1.92-2.00} \mathrm{Mg}_{0.00-0.03}\right.$ $\left.\mathrm{Fe}_{0.00-0.07} \mathrm{Mn}_{0.00-0.01}\right) \mathrm{Si}_{6.00} \mathrm{O}_{18}$.

Figure 1 presents the diffraction patterns registered for all studied beryl samples. Figure 2 shows an exemplary unit-cell packing for light pink beryl. Structure refinement details for all studied beryl crystals were shown in Table I (at the end). In the samples of yellowish beryl and blue beryl the presence of additional phases (quartz and albite, respectively) was observed.

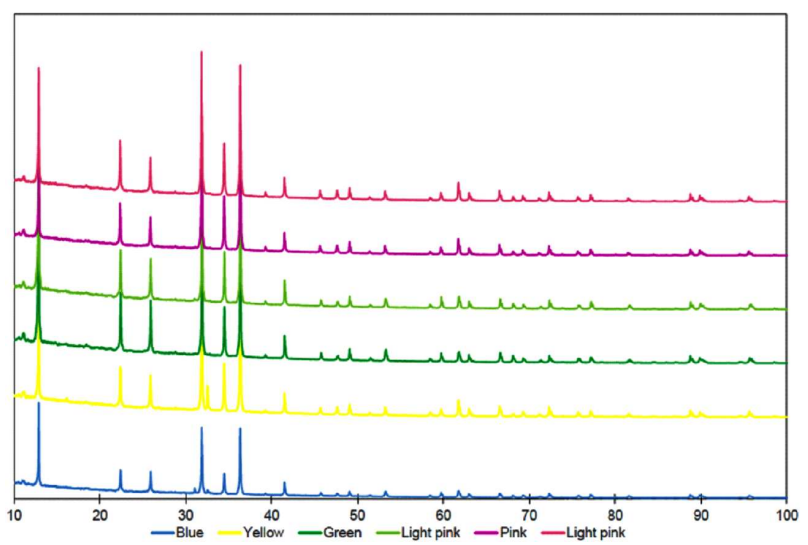

Fig. 1. Diffraction patterns for all beryl samples.

Aurisicchio et al. (1988), who studied beryl crystals by the single-crystal method, distinguished three compositional varieties of this mineral, dependently on structural site of the dominant substitution: octahedral, for which the substitution $\mathrm{Me}^{2+}$ for ${ }^{\mathrm{O}} \mathrm{Al}$ is dominant, tetrahedral with $\mathrm{Li}$ substituted for ${ }^{\mathrm{T} 2} \mathrm{Be}$, and normal with comparable sizes of both the replacements. They also presented effects of these substitutions on lattice parameters and $c / a$ ratio of beryl.

Based on $c / a$ ratio, we find that green, light green, and blue beryls with $c / a$ values in the range $0.997-0.999$

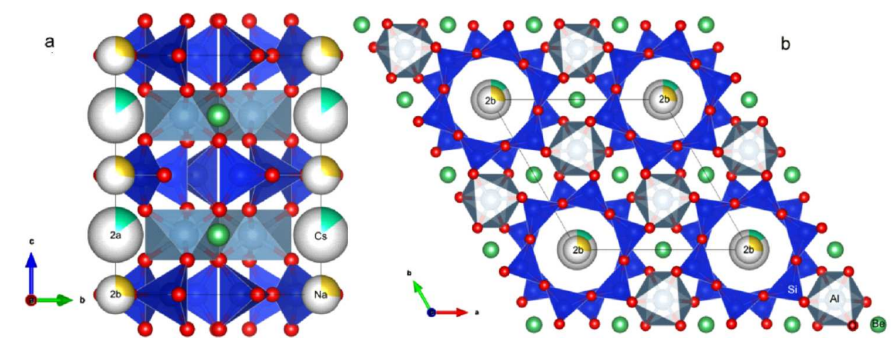

Fig. 2. Packing arrangement consistent with light pink beryl from Piława Górna. a) Projection along b, b) Projection along $\mathrm{c}$.

match best to the normal beryl class in accord with their chemistry and NYF affiliation of the host pegmatite. On the other hand, the yellowish, pinkish and light pinkish beryls, with $c / a$ values of $1.000-1.003$, represent the tetrahedral variety, also in accord with the LCT affiliation of the host pegmatite. None of the studied beryls represent the octahedral variety. Generally, the substitution of $\mathrm{Li}$ for ${ }^{\mathrm{T} 2} \mathrm{Be}$ is manifested by an increase in the $c$ unit-cell parameter, while substitution $\left(\mathrm{Fe}^{2+} / \mathrm{Mg}\right)$ for O Al elevates the $a$ unit-cell parameter.

\section{Conclusions}

The Rietveld structure refinement in cases of all the beryls allowed to corroborate their hexagonal structure corresponding to the space group $P 6 / m c c$. In spite of elevated $\mathrm{Li}$ amounts in the last group of the studied beryls, with the predominating replacement at the ${ }^{T 2} \mathrm{Be}$ sites, none of the samples showed the rhombohedral symmetry typical of pezzottaite.

\section{Acknowledgments}

This research was supported by a AGH UST grants no. 11.11.140.319 and no. 15.11.140.489.

\section{References}

[1] F.C. Hawthorne, M.A. Cooper, W.B. Simmons, A.U. Falster, B.M. Laurs, T. Armbruster, G.R. Rossman, A. Peretti, D. Günter, B. Grobéty, Mineral. Rec. 35, 369 (2004).

[2] O.V. Yakubovich, I.V. Pekov, I.M. Steele, W. Massa, N.V. Chukanov, Crystallogr. Rep. 54, 399 (2009).

[3] F.C. Hawthorne, P. Černý, Can. Mineral. 15, 414 (1977).

[4] A. Pieczka, E. Szełęg, A. Szuszkiewicz, S. Ilnicki, K. Nejbert, K. Turniak, in: 7th Int. Symp. Granitic Pegmatites, PEG, Ksiaż (Poland), 2015, Book of Abstracts, 75 (2015).

[5] I.L. Pouchou, F. Pichoir, in: Microbeam Analysis, Ed. I.T. Armstrong, San Francisco Press, San Francisco 1985, p. 104.

[6] C. Aurisicchio, G. Fioravanti, O. Grubessi, P.F. Zanazzi, Am. Mineral. 73, 826 (1988).

[7] J. Rodriguez-Carvajal, J. Phys. B 192, 55 (1993). 
TABLE I

Structure refinement details for beryl crystals from Piława Górna. Space group $P 6 / m c c, R_{p}$ - profile factor, $R_{w p}$ — weighted profile factor, $R_{e x p}$ - expected weighted profile factor, $R_{\mathrm{B}}$ - the Bragg factor, $R_{F}$ - crystallographic factor

\begin{tabular}{c|c|c|c|c|c|c|c|c}
\hline \hline Crystal & Composition & Unit cell, $a=b / c[\AA]$ & $V\left[\AA^{3}\right]$ & $R_{p}$ & $R_{\text {wp }}$ & $R_{\text {exp }}$ & $R_{\mathrm{B}}$ & $R_{F}$ \\
\hline blue & $\mathrm{Cs}_{0.08} \mathrm{Be}_{3} \mathrm{Al}_{1.66} \mathrm{Fe}_{0.23} \mathrm{Si}_{6} \mathrm{O}_{18}$ & $9.2239(1) / 9.2103(1)$ & $678.627(1)$ & 3.43 & 4.84 & 1.25 & 1.27 & 0.801 \\
yellow & $\mathrm{Cs}_{0.16} \mathrm{Be}_{3} \mathrm{Al}_{1.74} \mathrm{Fe}_{0.19} \mathrm{Si}_{6} \mathrm{O}_{18}$ & $9.2212(1) / 9.2240(1)$ & $679.244(1)$ & 3.96 & 5.45 & 1.10 & 1.31 & 0.918 \\
green & $\mathrm{Cs}_{0.06} \mathrm{Be}_{3} \mathrm{Al}_{0.88} \mathrm{Fe}_{0.54} \mathrm{Si}_{6} \mathrm{O}_{18}$ & $9.2238(1) / 9.2030(1)$ & $678.077(6)$ & 4.77 & 6.67 & 1.10 & 8.12 & 8.97 \\
light green & $\mathrm{Na}_{0.04} \mathrm{Cs}_{0.08} \mathrm{Be}_{3} \mathrm{Al}_{1.80} \mathrm{Fe}_{0.20} \mathrm{Si}_{6} \mathrm{O}_{18}$ & $9.2206(1) / 9.2049(1)$ & $677.746(1)$ & 5.20 & 7.47 & 1.14 & 8.94 & 7.60 \\
pink & $\mathrm{Na}_{0.29} \mathrm{Cs}_{0.17} \mathrm{Be}_{3} \mathrm{Al}_{2} \mathrm{Si}_{6} \mathrm{O}_{18}$ & $9.2210(1) / 9.2302(1)$ & $679.672(6)$ & 4.23 & 5.91 & 1.20 & 6.81 & 6.29 \\
light pink & $\mathrm{Na}_{0.26} \mathrm{Cs}_{0.16} \mathrm{Be}_{3} \mathrm{Al}_{2} \mathrm{Si}_{6} \mathrm{O}_{18}$ & $9.2212(1) / 9.2284(1)$ & $679.575(5)$ & 3.83 & 5.23 & 1.16 & 3.81 & 3.42
\end{tabular}

